once admitted that mildness in one of his articles was not "the softness of the answer which turneth away wrath, but... that of the pillow which smothered Desdemona". As the foremost gladiator of science in his day, he knew how to use every weapon. He thereby changed the mind of his own generation and of our own as well.

Sir Crispin Tickell is at Green College, University of Oxford, Woodstock Road, Oxford OX2 6HG, UK.

\title{
Roots theories and racist interpretations
}

\section{Race and Human Evolution: A Fatal Attraction \\ by Milford Wolpoff and Rachel Caspari \\ Simon \& Schuster: 1996. Pp. 462. \$25, E17.99. \\ Leslie C. Aiello}

This book attempts to answer one of the most fundamental questions of human existence: why are we here? In doing this, the authors put forward one of the best and most clearly articulated cases so far for the multiregional theory of modern human origins. Perhaps more importantly, they couch their description and defence of this theory in the context of the intermeshed history of human origins studies, racism and politics. For this reason alone, students of human evolution should read and take heed of this book. It is too easy for us to sit in our universities and ignore the intellectual history of the theories that we put forward and the ways in which they may be manipulated by the political and cultural contexts in which we work.

Wolpoff and Caspari are careful to define multiregionalism as a theory that suggests that for some two million years human populations have been entwined in a network of widespread peoples who evolved together because they met and interbred, giving the races today many ancestors, not a single common one. This gloss on multiregionalism is different from that commonly associated with the theory by the popular press and many who argue against the idea.

The popular interpretation of multiregionalism is that races of Homo erectus in Africa, Asia and Europe gave rise to the modern human races living in those areas of the world. The implication is that, during the long course of evolution, isolation rather than continuity was the rule. Wolpoff and Caspari argue strongly that this unjustified emphasis on isolation in human evolution exposes the theory of multiregionalism to equally unjustified racist interpretations. At the same time, they stress that it also renders the theory unreasonable in the context of Darwinian evolution. Throughout the book, they return again and again to the point that modern multiregionalism is not a polygenetic theory of racial evolution.

\section{IMAGE UNAVAILABLE FOR COPYRIGHT REASONS}

A Homo erectus skull: racism rears its ugly head in interpretations of human origins.

Polygenism is the largely nineteenth-century idea that human races have different origins and separate histories. Most polygenetic theories formulated after Darwin posited some type of orthogenetic impetus driving the evolution of these isolated races in the same general direction. The more separate the human races are, the easier it is to argue that some humans are more human than others, and to build a justification for colonialism, racism and slavery. This is precisely how these theories were used.

Wolpoff and Caspari show that, although polygenism is a convenient prerequisite to racism, all polygenists were not necessarily racists, and that all adherents of the alternative view, monogenism, were not necessarily enlightened egalitarians. Rather, racism then as well as now is governed by a complicated interplay of influences from natural history and taxonomic thinking, religion, politics and, from the middle of the nineteenth century, Darwinism in its various guises. Much of the core of the book traces these various threads through the personalities involved in late nineteenth and early twentieth century physical anthropology and racial studies. In so doing, it establishes intellectual genealogies which make fascinating reading for anyone familiar with the work of the personalities involved.

This discussion sets the stage for the defence of one of the most respected hominid anatomists of the twentieth century, Franz Weidenreich, and his perhaps less respected polycentric theory of human origins. It is no accident that the book builds up to this climax, because Weidenreich's polycentric theory is the immediate intellectual forerunner of multiregionalism. Wolpoff and Caspari argue strongly that Weidenreich viewed human races as continuous, interconnected and ephemeral entities with considerable time depth. To their mind, poly- centrism has been seriously misrepresented by modern palaeoanthropology as simply another polygenetic theory, incompatible with modern evolutionary biology and open to racist interpretations.

By association, they also feel that multiregionalism is unjustifiably tainted. Wolpoff and Caspari are also careful to distance multiregionalism from another and perhaps infamous version of polycentrism put forward in the 1960 s by Carlton Coon. In emphasizing the discontinuous nature of human races, Coon's theory harks back to some of the worst excesses of nineteenthcentury academic racism.

On this basis, the last three chapters of the book are devoted to the defence of modern multiregionalism. Most of the arguments presented are well known to palaeoanthropologists, but the clarity with which they are presented makes Race and Human Evolution a welcome contribution to the literature. However, the book is not in itself going to convince the majority of the academic community that alternative single-origins theories for the evolution of modern humans are dead. This is particularly the case because Wolpoff and Caspari insist on polarizing the debate. They argue against what they insist on calling the "Eve theory", the most extreme version of a variety of single-origins models for modern human evolution.

The real question is whether their own theory of multiregionalism is genetically viable. Is it really possible that modern human features could have arisen individually and at different times and places throughout the vast geographical range occupied by Pleistocene human populations, and coalesced into modern humans and modern human diversity as we know it today? Many palaeoanthropologists and evolutionary biologists will remain to be convinced even after reading this book. We can expect this lively debate to continue for a long while to come.

Leslie C. Aiello is in the Department of Anthropology, University College London, Gower Street, London WC1E 6BT, UK.

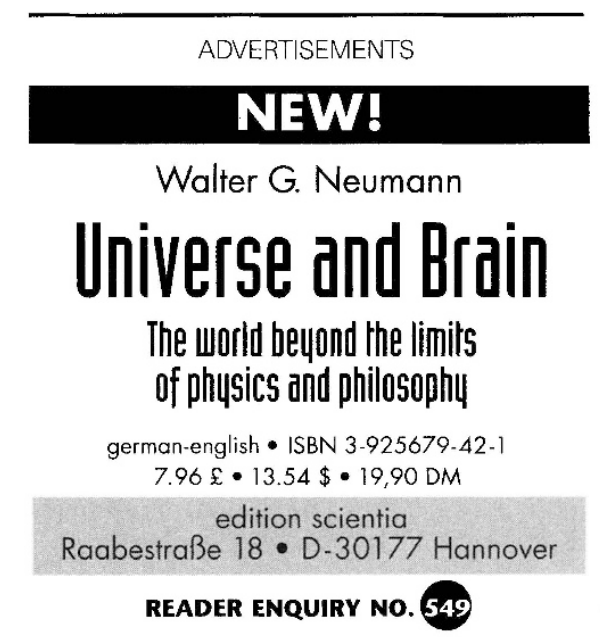

